\title{
Peace, Protest and Precarity: Making Conceptual Sense of Young People's Non-violent Dissent in a Period of Intersecting Crises
}

\author{
Benjamin Bowman ${ }^{1}$ (D) Sarah Pickard ${ }^{2}$ D
}

Received: 28 July 2021 / Revised: 30 November 2021 / Accepted: 1 December 2021/ Published online: 20 December 2021

(C) The Author(s) 2021

\begin{abstract}
The current young generation are living through socio-historically situated intersecting crises, including precarity and climate change. In these times of crisis, young people are also bearing witness to a distinctive global wave of youth-led activism involving protest actions. Much of this activism can be deemed dissent because many young activists are calling for systemic change, including the radical disruption, reimagining and rebuilding of the social, economic and political status quo. In this interdisciplinary article, between politics and peace studies, we investigate how the concept of peace plays an important role in some young dissent, and specifically the dissent of young people taking action on climate change. We observed that these young environmental activists often describe their actions in careful terms of positive peace, non-violence, kindness and care, in order to express their dissent as what we interpret as positive civic behaviour. They also use concepts grounded in peace and justice to navigate their economic, political and social precarity. Based on a youth-centred study, drawing on insightful face to face semi-structured interviews in Britain and France with school climate strikers, Friday For Future (FFF) and Extinction Rebellion (XR) activists, we explore how young environmental activists themselves related their dissent, and especially how they attached importance to it being non-violent and/or peaceful. Stemming from our findings, we discuss how young environmental activists' vision of violence and non-violence adapted to the structural and personal violence they face at the complex intersections of young marginalization, global inequalities and injustices in the lived impact of climate change and the policing of protest.
\end{abstract}

Keywords Young people $\cdot$ Young environmental activists $\cdot$ Peace studies $\cdot$ Nonviolent protest $\cdot$ Precarity $\cdot$ School climate strikes

Benjamin Bowman

B.Bowman@mmu.ac.uk

Extended author information available on the last page of the article 


\section{Introduction}

"To make peace among people we need to make peace with the Earth" (Shiva 2019: 6)

The history of young environmental activism is long and global. In this article, we focus on recent history, since 2018, of a world-wide wave of youth-led and youth-centred environmental activism, which has moved public and political debates towards taking greater action on climate change (Hayward 2021; Nissen et al. 2021; 2020; Collin and Matthews 2021). This wave of environmental activism marks a "watershed" moment in climate action (Pickard et al. 2020: 251) that needs to be more contextualized and conceptualized (beyond the numbers and policy outcomes), so as to provide a greater understanding of this young generation. We contribute our conceptual approach to radical kindness in young activism (Pickard et al. 2020) as well as our theoretical exploration of young people's environmentalist activism during intersecting crises to a growing literature on young people's action during climate change.

We are led in our conceptual thinking by the work and the voices of the young people who have shared their thoughts with us in interviews, including Oliver, 28, involved in the Extinction Rebellion protest fortnight in London, in October 2019 who commented: "We are radically non-violent". Where possible, we have used the words, concepts and terminology we heard from young people. One aspect of young environmental activists' discourse that stood out was the importance of non-violent protest actions and peaceful actions. Many of them described their actions in terms of positive peace, i.e. non-violence, kindness, care and justice, in order to express their dissent as positive civic behaviour. Dissent, to clarify, is a term that refers to the ways in which young people are not simply calling for change within existing political system, but they also dissent from that system, and call for systemic change on a global scale. This theoretical article stems from and draws on our qualitative study that included interviews with young environmental activists in 2019 and early 2020. These interactions provide valuable qualitative insights not captured in survey data.

Humanity's situation is precarious, but that "optimism is contagious ... I was feeling depressed. If we get together, we can focus on hope" (Skylab, 19, interviewed at the XR protest in London, October 2019). The young people we worked with tended to focus on hope in times of crises and, as Skylab puts it, tended strongly to see optimism as something that flowed from sharing and collaboration with others. They also used concepts grounded in peace to navigate their economic, political and social precarity, in times of intersecting environmental, economic, political and social crises, and amid the criminalization of protest and situated injustices (Bessant 2021).

The concept of peace is, we think, not yet adequately examined in this growing field of literature on young people's experiences, and action, with respect to climate change. For this reason, our article is led by young people but provides what we hope is a strong academic conceptual basis for concepts like peace, violence 
and young people's political repertoires in this context. According to John Foran, "one way to think of the present moment and the foreseeable future is as a triple crisis of economics, democracy, and pervasive violence" (Foran 2019: 109). The sociologist makes the crucial link between crises, violence and environmental activism of marginalized groups that include young people: "Climate justice perspectives recognize that the brunt of climate change and environmental injustice falls hardest on the most poor and marginal peoples" (Foran 2019: 110). Furthermore, according to Foran, "the ends of justice are no longer held to justify the means of violence, but the means of non-violent resistance reflect and guarantee the ends that they seek" (Foran 2019: 112). We provide our theoretical and conceptual analysis as a way to support the application of these theories by young people themselves, as well as by their allies.

Crucially, we argue that the ways in which many young environmental activists themselves conceive of peace and protest can provide perspectives and lead scholars across disciplines towards new, youth-led concepts of what it means to dissent and protest. While the current wave of youth-led activism is global in its scale and historic in its influence, the "prevailing methodological tools and framings" for analyzing young people's (protest) action remain adult-centred, and researchers have been caught "on the back foot" by the need to establish youth-centred tools for youth-led activism (Wood 2020: 217). Typical methodologies and analytical frameworks, often based on survey data and pre-existing adult concepts of the political, the environmental and so forth, limit research in many ways. For instance, they tend to impose unhelpful dichotomies of the political and non-political on young people's repertoires of activism (Bowman 2019), to overstate young individual autonomy and to neglect the importance of older allies, family members, teachers and other adults (Wood et al. 2018), as well as their collective rather than individual identities (Wood 2020: 220). Consequently, the voices of young people are woefully absent in typical analyses and especially in survey approaches.

In our study, we attempt to listen carefully to what young environmental activists are saying and expressing - their voices-and we contextualize, in order to better theorize from the positions of young people themselves. Through our youth-centred study, we explore how young environmental activists themselves related their dissent, and especially how they attached importance to it being non-violent and/or peaceful. We specifically consider the role that the concept of peace plays in young dissent during the wave of environmental activism since 2018. While this work is authored by academics, we have attempted to follow from what we learned from young people, and to provide a framework that we hope will be supportive of young people as they apply concepts like peace in their climate activism. Our research question is: What are young environmental activists talking about when they speak to us about peace and peaceful protest?

First, the article outlines the background to the study and our methodology. Then, follow our findings and a discussion of how young people's vision of violence and nonviolence adapted to the structural and personal violence they face due to the complex intersections of young marginalization, global inequalities in the lived impact of climate change and the policing of protest. We hope our conceptual work, and our exploration 
of the voices and experiences of the young people who shared their environmentalist action with us, will be of use to young people themselves and to adults who support them, as well as educators and researchers with an interest in climate change and young people's environmentalist politics.

\section{Background and Methodology}

This article builds on academic work across disciplines about young people and political participation, especially protest actions (Grasso 2017; Pickard 2019; Andretta and della Porta 2020; Watts 2021). This is to highlight the relevance of peace and kindness as a means to comprehend the actions of contemporary young environmental activists in particular.

It evolved from observations and reflections we made about our interviews with young environmental activists. During these interviews, we noticed that young participants referred to how attached they were to non-violent protest, kindness and peace. It was important for them that the protests they were involved with were not confrontational and very deliberately centred on non-violent or peaceful text, commonly referred to by scholars as a repertoire of contention (Tilly 2003) characterized by non-violent direct action. Some also mentioned spontaneously that their own stance was "very different", i.e. diametrically opposed to police violence that they had encountered, as well as (obliquely) the violence of governmental policy.

This article results from 60 face-to-face semi-structured interviews with young environmental activists between the ages of 11 and 34, before and during large school climate strikes, Fridays for Future (FFF) and Extinction Rebellion (XR) protest actions, notably the FFF "Global Week for Future" 20 to 27 September 2019, notably the or "Global Climate Strike" on Friday 20 September 2019 and the XR "International Rebellion" from 7 to 19 October 2019. They took place in different locations in Britain (London, Manchester, Nottingham and Sheffield), where large actions were taking place. A minority of participants were first contacted prior to protests via social media, others were approached during protest actions. For participants interviewed in the field, we approached them to ask about their placards, which provide illustrations throughout this article (see Photographs 1, 2, 3 and 4). All participants signed ethical consent forms before being interviewed and knew they could leave the interview at any point. For interviewees below the age of 16 , prior signed parental consent was obtained. Some participants gave pseudonyms that do not always reflect their gender or ethnic background. Interviews lasted from $15 \mathrm{~min}$ to $2 \mathrm{~h}$. Data were gathered during interviews and transcribed, read carefully and coded by the research team in a process of thematic analysis. Our photographs are used as illustration, but within the remit of this article, we do not undertake a detailed visual data analysis of these. 


\section{From Slow Violence to Youth-Led, Climate Peace}

Climate peace, in young people's environmental activism, is a transformative approach to the climate crisis that envisages a fundamental shift in human society towards justice and interdependence. More specifically, because climate change is a form of "slow violence" (Nixon 2011), climate peace, and by extension climate peacebuilding (i.e. the building of peace), is an approach to climate change that seeks to reimagine and reform human society away from conditions of violence and towards peace. Climate peace is an approach to climate change that recognizes and builds interdependence among people, as well as between people and their envi-

Photograph 1 Global Climate Strike, 20 September 2019, Manchester, UK (Bowman 2020)

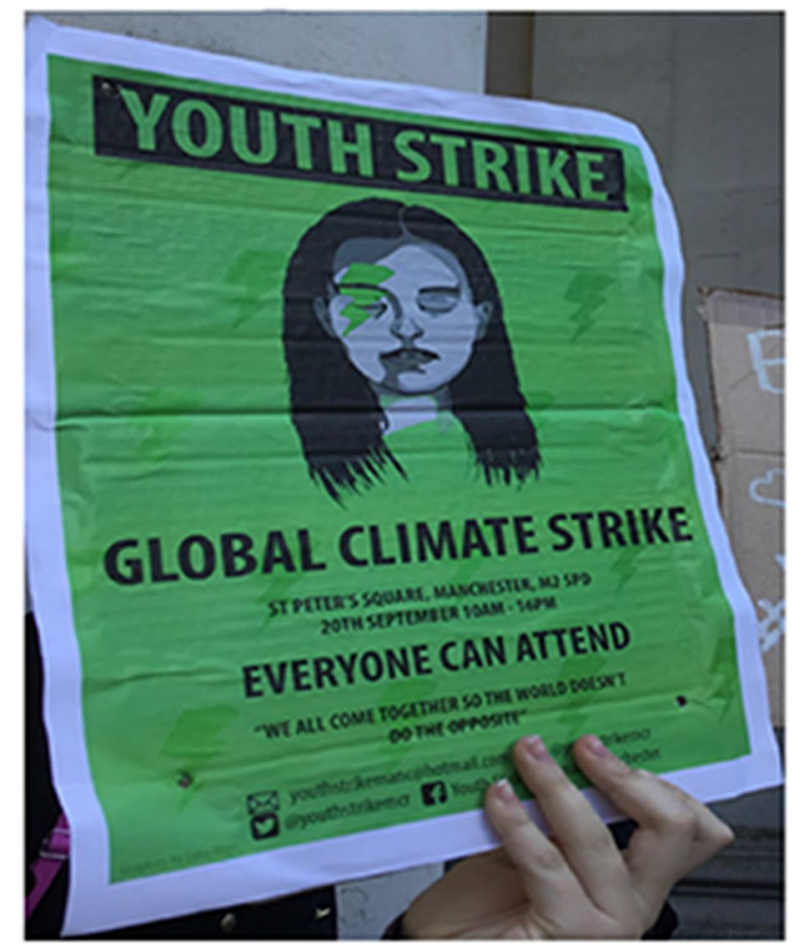

ronment, and which calls for and works for climate justice. Young environmentalist activists witness the violence of climate change, and they want to build climate peace. Much of their activism is characterized by calls for justice, interdependence and understanding, as well as transformative "system change". Our concept of climate peace develops from the theoretical approach to climate change as a form of "slow violence" (Nixon 2011). Climate peace is a powerful conceptual tool for understanding young people's environmentalist activism for two reasons. First, theoretically speaking, climate peace offers a conceptual approach to climate change activism that releases some of the limitations that traditional approaches to activism impose on the study of young people's politics, as we discuss below. Second, 
empirically speaking, peace and the discussion of related concepts like non-violence, interdependence and care occur frequently in interviews with young people.

Peace is a useful theoretical tool and a familiar concept among young people themselves. Yet, peace barely figures in political science and social movements disciplinary studies of the current wave of young environmental activism. Political science studies often restrict analysis to simplistic and reductive approaches, such as the classification of young people's behaviour according to a binary definition of the political and non-political (Bowman 2019); the outdated binary division of "conventional" and "non-conventional" political participation (Pickard 2019); the study of young motivations that focus on the individual demonstrator in isolation (Wood 2020); the use of reductive concepts of environmentalism that limit analysis by imposing narrow, dehistoricized and technocratic assumptions about what environmental activists want to achieve (Curnow and Helferty 2018).

Taking an interdisciplinary approach allows scholars to access a wider range of analysis, and across disciplines, war and violence are familiar frames for considering climate change and the wider environmental crisis. A significant example of this is the convergence of corporate and state power to impose an economy "based on the idea of limitless growth", which was compared to a war economy by Vandana Shiva. She posits "the war against the earth becomes a war against people, against democracy and against freedom" (2012: 5). Climate change is one outcome of an economic system based on extraction and injustice. Similarly, in his work on the environmentalism of subaltern and marginalized groups, Rob Nixon refers to climate change as slow violence, "a violence that occurs gradually and out of sight, a violence of delayed destruction that is dispersed across time and space, an attritional violence that is typically not viewed as violence at all" (2011:2). Climate change is a form of violence typically not viewed as violence by mainstream frames of analysis. Mainstream analysis does not focus on the injustice of an economic system causing climate change, especially in the Global South. It focuses on technical adjustments which can make that same economic system sustainable. On the contrary, we observe that young people's protest actions are often characterized by the call for "system change, not climate change". The motivation among such young people to imagine a new economic system based on justice, solidarity and interdependence is well documented (Järvikoski 1995; Pulido 1996; Fisher 2016; O’Brien et al. 2018; Trajber et al. 2019; Bowman 2020; Nissen et al. 2021; Sloam 2020).

We argue that young people's action on climate change is a form of peacebuilding. This conceptual approach constitutes a break with the traditional ways of considering young people's action in political science. Furthermore, we suggest that the peacebuilding approach among young environmental activists is established in ways that typically evade view and escape analysis from scholars. We contend that climate peace, which is a transformative approach to climate change based on a fundamental shift in human society towards justice and interdependence, evades view, partly due to the tendency of adults in power and adult-centred institutions to abstract young people from political agency, or to devalue, dismiss and discredit their political agency (Bessant 2021; Pickard 2019; Young-Bruel 2012). We bring 
together our approach to peace and peacebuilding with an analysis of contemporary young dissent within the climate change movement.

Young people's approach to climate peace, which we consider could be called a radical kindness approach (Pickard et al. 2020)—with our gratitude for this term due to Skylab, 17, a young environmentalist activist who spoke to us in London-is characterized by three features: first, a focus on climate justice as opposed to sustainability (Foran 2019); second, the search for community, cooperation, conversation and sharing in response to intersecting oppressions and injustices including at a global scale; and third, repertoires of dissent that call for "systems change, not climate change". Young people are attempting to build climate peace through repertoires of political contention within a political context where both climate peace and young dissent remain difficult concepts for traditional analyses to grasp; young people work for peace at a time when their contention is obscured by assumptions about the place of young people in democracy, and peacebuilding itself remains hard to imagine.

Peace studies as a discipline was founded in the 1960s by Johan Galtung. The Norwegian sociologist wrote on two distinctive forms of peace: positive peace and negative peace. Positive peace, according to him, is a process of human integration, whereas negative peace is peace merely as the absence of violence (Galtung 1969). His concept of positive peace is the centre of peacebuilding approaches based on what Diana Francis (2010) calls "shared interdependence"; the building of peace through interdependence must be distinguished from peacekeeping through dominance, which is merely the establishment of "stable hegemony" over the use and non-use of violence (Francis 2011a, b: 508). Peace scholars usually pay most attention to young people when considering peacebuilding approaches in schools (Bickmore 2005, 2011; Brantmeier 2007) and in neighbourhoods or regions where violence is common (McEvoy-Levy 2011; Roque 2017). In her work on children, youth and peace in conflict zones, Siobhan McEvoy-Levy (2011) writes that young people face barriers to involvement in peacebuilding including "adult gatekeepers [who] often limit youth involvement and protect their own turf" and the conceptual contestation, manipulation and politicization of "ideas of 'children' and 'youth"”. (160). Furthermore, for Kurtenbach (2017: 2), young people tend to be abstracted from adult concepts and processes of peacebuilding as "the inclusion of youth ... rarely includes elements other than education or training".

The preoccupation within adult politics, when it comes to young people, is whether young people are engaged: that is to say, whether they are engaged with civic and political institutions and whether they are in education and training that prepares them for civic and institutional engagement. Yet, the politics of young environmental activists exists irrespective of institutional engagement. Indeed, the most common mode of young environmentalist action is the school strike, which is specifically the withdrawal of young people from education and the refusal to engage. We consider that their peacebuilding work, or rather the peacebuilding concepts and processes that young people theorize, develop and apply in their environmentalist action, is less visible to scholars, policymakers, practitioners and other empowered 
adults precisely because these concepts are young people's theories, young people's concepts and young people's actions. For this reason, young environmental activism challenges those institutions, not just for its transformative potential, but merely because it exists without the need for schools and education/training, without adult gatekeepers and regardless of their inclusion in adult-dominated institutions. In the next section of this article, we reflect on the burden of the political that compels young people to engage with adult-dominated institutions.

\section{The "Policy Sprout" Dilemma and the Burden of the Political}

That young people tend to be sceptical about the efficacy of institutional politics is a familiar claim in youth studies and political sociology literature (see, e.g., work by Henn et al. 2002; Pontes et al. 2019 on "engaged scepticism"). Taft and Gordon (2013) write that young people's participation in adult institutions tends to be marked by "manipulation, decoration, and tokenism". They quote a young person who complained that she and her peers were treated as "policy sprouts" (2013: 93), tokenized and asked for participatory input on policies that adults had already resolved to carry out (Chevalier and Loncle 2021). Young people who are "policy sprouts" may also find that after they have engaged with adult institutions, adults will follow up with policies that do not meet young people's demands or, indeed, go contrary to what young people advised. Regardless of whether young people were actually listened to, adult power brokers can apply a sheen of legitimacy to policy by claiming that young people engaged with it. In other words, adults in power and adult-led institutions can claim young people have participated and engaged in a policy process, even if the process was a tokenistic or tick-boxing consultative exercise. By claiming that young people were engaged, they can reinforce and legitimize the project as participatory, youth-consultative and empowering, even if the participation of young people was manipulated, decorative and tokenistic. Of course, the "policy sprout" dilemma cuts both ways, and many adults in power may well be treating young people as "policy sprouts" despite good intentions. We have already argued, in this article, that traditional political and analytical concepts have limited utility for working with young people.

In terms of the current wave of young environmental activism since 2018, the "policy sprout" dilemma was raised on the international stage, among others, by the prominent young environmental activist Greta Thunberg who spoke to the United Nations Climate Action Summit in September 2019 declaring: "I shouldn't be up here ... How dare you pretend that this can be solved with just 'business as usual' and some technical solutions?" (Thunberg 2019). As Thew et al. (2020: 2) argue, even when young people are formally recognized as participants; it can result that "youth participants are hindered by the exercise of power by other stakeholders which shapes the informal rules of participation and accepted discourses". The "policy sprout" dilemma is not just that 
the opportunities for young people to participate in policymaking are rare, but that participation itself becomes a tool by which adults can manipulate the process and decision-making. Methodologically, we consider, the "policy sprout" dilemma moves us towards the concept of climate peace as a way to get beyond familiar but limiting concepts like political engagement, civic activism and environmentalism, as well as to build from the theoretical position of the young people who have shared their activism with us. We heard young environmental activists speaking about peace and we hope our concept of climate peace helps to shift the conceptual focus onto the work some young people are doing, as opposed to the way young people fit into the concepts, structures and institutions of adult-centred politics.

By focussing our conceptual lens on climate peace and peacebuilding among young people, we act to recentre the concept of political action on young people themselves. That means we use climate peace as more than a reflection of the words and terms that young people in our study used. Climate peace is a conceptual framework that does not privilege education, training, participation, engagement, policy involvement, or visible and easily identifiable political acts among young people. On the contrary, young people's concepts and actions for climate peace are likely to evade view and escape analysis, specifically because they derive from young people themselves and correspond to the slow violence of climate change. We recognize that young people's acts can be politically intentional or non-intentional, and be purposive either way (Isin 2005: 374). Our analysis, therefore, does not attempt to typologize the political versus the non-political or engagement versus disengagement, or to burden young politics with the need to be clearly defined as intentionally political. As Tracey Skelton (2010: 148) writes, young people often use everyday lived experience as a way to undertake political tasks like considering "present possibilities of reconciliation across difference". Young people's emotional commitments and explorations of feelings like anxiety about climate change can be part of, and generative of, action (Pihkala 2017: 2). We focus on young people's peace work and not on the process of classifying this work as engaged, political or otherwise. Binary approaches to classifying young people's action continue to limit much academic work across youth studies and including in the study of young people's environmentalism, as we have elsewhere argued (Pickard et al. 2020).

The current young generation are living through "socio-historically situated intersecting crises", as the editorial of this special issue points out. Young people's environmental activism is characterized, we argue, by a tendency towards a peacebuilding approach to the slow violence of climate change, and a preference for founding analysis in an "interdependence approach" to life (Francis 2010: 75). These are based on exploring positionalities and forging solidarities (Bowman 2020), as opposed to the advocacy of new policy frameworks or political leadership that can end the violence of climate change through the imposition of a new hegemonic order. If climate change is a form of violence, then the distinction between these forms of peace is critical. 
We posit that young people's environmentalism is distinctive for two reasons. First, young environmental activists tend to work to imagine and envision webs of global interdependence, action and justice. Second, mainstream environmentalism tends more often to advocate the imposition of specific policies, plans and other economic and social developments to control or mitigate climate change.

\section{Non-violence in Young People's Dissent}

In our analysis of climate peace and peacebuilding among young environmental activists in our studies, we also accommodate the study of non-violence. Non-

Photograph 2 Global Climate Strike, 20 September 2019, Manchester, UK (Bowman 2020)

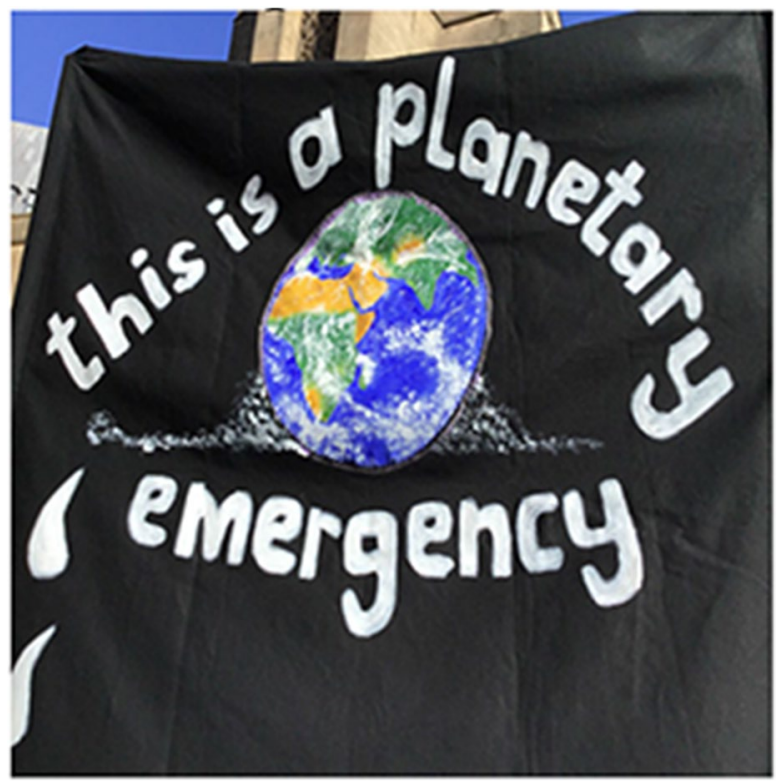

violence, we contend, is related to peace but distinguishable. Martin Luther King, Jr. (2016: 49-53) writes that "strongly active" non-violence is oriented towards persuasion and not dominance, community and not hegemony, and towards justice. We met Drew, 16, at a climate strike in Manchester holding a sign that said "Waves of Support" and depicted waves of hands bearing each other upwards across the sign. Drew's vision of the movement was that "everyone's involved, everyone has a say in what's happening". Sharing of voices and experiences and the building of community was prevalent across our study, as in Drew's words, not as the absence of hierarchy or the resistance to dominance 
but, precisely, as processes of building just communities in which-at least in the visions of the young people we spoke to-everyone can be involved. We apply King's definition of non-violence to the experience of young environmental activists.

Non-violence in the context of young environmental activism is also, vitally, a response to policing. Since the turn of the millennium, protest policing has been increasingly characterized by the criminalization of protest (Power 2012) through public order legislation and policing strategies, the use of violent police tactics including surveillance and physical violence (Pickard 2014), the disruption of movements (Gilmore et al. 2019) and by demonization in certain sections of the press (Pickard 2019; Muncie 2019).

For instance, many of our participants were interviewed in Britain, where the public order offence of "violent disorder" carries a 5-year maximum custodial sentence plus a fine. Neither requires violence or disorder to actually happen for a conviction to be made. The police only are required to suspect a subjective "threat" "would cause a person of reasonable firmness present at the scene to fear for his personal safety", regardless of whether a person of reasonable firmness is there at the scene. As observers, we witnessed peaceful protestors (XR Red Brigade) being prohibited from leaving a certain part of Trafalgar Square, and the following day tents used by interviewees (including Skye, 20, wearing a "We act in peace" patch) were removed due to a public order that was subsequently overturned by the High Court (Pickard 2021). Nina Power (2012: 416) documents the use of violent disorder as a charge against "unarmed, unprotected, weaponless, often very young" student demonstrators who, prosecutors argued, presented a terrifying threat to riot police. Very deliberately peaceful demonstrators, including the young activists who took part in our study, must foresee a possible, future accusation that they were threatening, even if there is no violence or disorder. The definition of threat is subjective, and the possible penalties for young people who are later deemed to have been threatening are harsh.

We contend that young environmental activists use concept of non-violence based on two poles, which frames both positive and negative forms of peace. We use these terms in order to distinguish what, in our analysis, are two different types of peace that we perceive in non-violent activism among the young activists in our study. It is positive peace because the very deliberate non-violence of the activists is oriented towards persuasion, community and justice; it is negative peace because the non-violence is oriented towards the disavowal of violent tactics and the rhetorical imposition of words and acts in which the absence of violence is as direct and clear as possible. This is in order to preempt those who may seek to define their action as threatening (physically and morally), and especially in response to the criminalization of protest. Young environmental activists appeared perplexed regarding policing responses to their youth-led peaceful protest actions about governmental inaction on the existential issue of the environmental crisis. 


\section{Imagining Peace: “Community, Not Hegemony”}

Laura Pulido identifies the concept of "subaltern environmentalism" among "those who are highly marginalized both economically and socially" whose lives are "structured by domination" (1997), including structural racism and economic inequality. For Pulido, "the issue of positionality is most important in distinguishing mainstream and subaltern activism" (1996). Positionality in this case refers to young people and their relative positions in unequal structures of power such as, but not limited to, social class, location, age, gender and race. From a peacebuilding perspective, the central role that positionality plays in young people's environmental activism (Bowman 2020) can be considered a form of non-violent strategy that builds community, rather than establishes hegemony (King 2016: 49-53).

Photograph 3 Global Climate Strike, 20 September 2019, Nottingham, UK (Pickard et al. 2020)

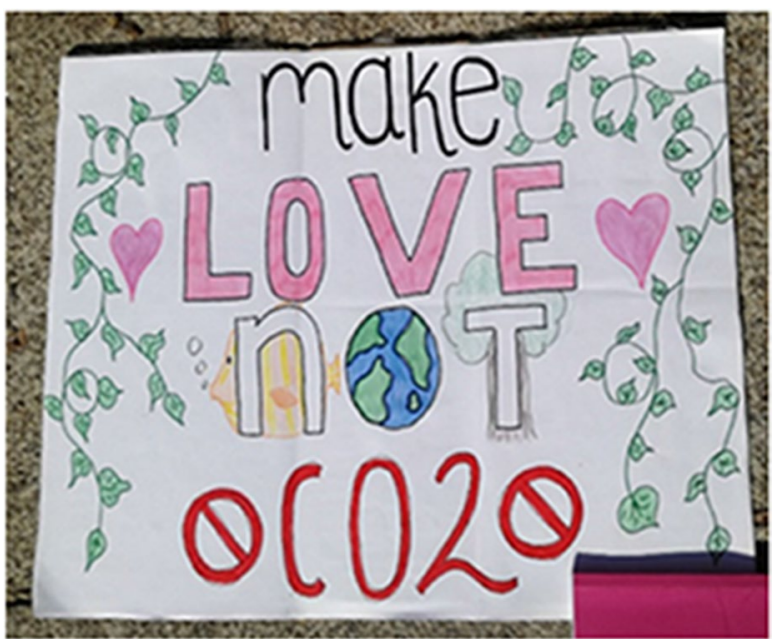

Commentary external to young activism (i.e. reportage and academic research that sits outside the circles and conversations of young activism and looks in) often judges young people's action to centre around simple and direct claims about scientific truth or the hegemony of a correct approach to the climate crisis, claiming, for instance, that "a simple but unambiguous message emerged as a common denominator of these individual groups: "listen to the science"" (Schinko 2020). We posit that approaching young people's environmentalism in the search of simple and unambiguous messages is part of what Curnow and Helferty (2018) call the "mainstream" environmental movement, which frames "the goals of the environmental movement in narrowly constructed, technocratic and dehistoricized ways". On the contrary, we argue, young people's environmentalism is characterized by the exploration of positions and the building of community. For this reason, we distinguish young environmentalism as a peacebuilding approach to climate peace. In Kishinani and Smith's student-authored Student Guide to the Climate Crisis, they argue that climate change requires "difficult conversations. Not everyone will agree, 
but that's the whole point-we need everyone to participate in these conversations. We need to work together, despite our differences" (2020: 23). Young environmental activists often speak about change as a grassroots process. They call for conversations, sharing, hope and interdependence.

Skylab, a white, 19-year-old student, had travelled to London for the XR protest fortnight in October 2019. She had been camping in two designated sites (St James' Park and Vauxhall Square), but had been moved along by the police to Trafalgar Square, where she reflected on how taking part in the environmental protests as having a positive effect on mental health for a variety of reasons:

I've not slept in the same tent all week. I don't have my own tent... There is always someone who cares, who has space.

We need to address regenerative change.

This was a very common comment among young environmental activists of all ages: Skylab had met Mitch, an unemployed white 20-year-old who said: "Everyone needs to be part of a community. Everyone needs to look after each other and if we don't, that's how things spiral out of control".

This reflects what the academic Panu Pihkala writes, "eco-anxiety emerges as an adaptive response to the vast socio-ecological problems of our time" (2020), and emotions like depression and grief are often cited by young environmental activists and specifically that acting together and supporting each other provide hope. While young environmentalism includes messages of protest and advocacy for specific, narrowly constructed policies, it is the development of relationships of care and support that characterize the protest actions we attended and the interviews we had with young people. These relationships, we posit, fit within a broader literature on subaltern environmentalism characterized by the exploration of positionalities. The young environmental activists we spoke to told us they felt like a minority voice, but that being able to share with others helped them. Jay, 32, spoke in Trafalgar Square during the XR October 2019 protest fortnight, and she said: 'I've been waiting for this for ten years. It is taking me time to deal with the grief and feel like there are other people. I'm not alone". Similarly, Curtis, 21-year-old student in Trafalgar Square: 'I'm listening to some other people talking and some people opposing ... and it makes me upset how many people don't realise how important it is. I'm proud that there are other people here who care about the environment and believe it's something important. ... It's comforting to know".

Peace provides a powerful conceptual tool for making sense of the complex relationship between emotions, community, support and the exploration of positionalities that take place among young people in environmentalist movements. We proffer the conceptual analysis that in a period of intersecting crises, the current movement of young environmentalism is forming around a peacebuilding approach, and specifically one that seeks to explore the opportunities for an "interdependence approach" between people (Francis 2010: 75). The characteristic young approach to climate change, according to our conceptual analysis, is not to achieve sustainability but to achieve global climate justice and peace. We agree that these young people "are challenging power relationships and political interests to promote climate-resilient futures" (O'Brien et al. 2018). However, the activism of young people is characteristically about community building, rather than policy advocacy. Young people, on the whole, do not start with a clear idea of climate 
resiliency, or policies for sustainability, and then seek to impose it. They do not seek to replace the existing hierarchies of power with new, sustainable hierarchies. They do not simply want to hand power to greener politicians with greener policies. They want power to be shared differently, and to challenge institutional politics itself. Young environmental activism begins and crystallizes, we argue, with the wish to build community, to explore interdependence and to establish the groundwork for climate peace.

\section{World Peace and Exploring Conflict Transformation}

Peace is a powerful concept that helps explore the global vision of young environmental activists in the process of imagining new worlds, not saving the one that exists. While the Earth tends to figure large in the activism of environmentalists of

Photograph 4 Global Climate Strike, 20 September 2019, Nottingham, UK (Pickard et al. 2020)

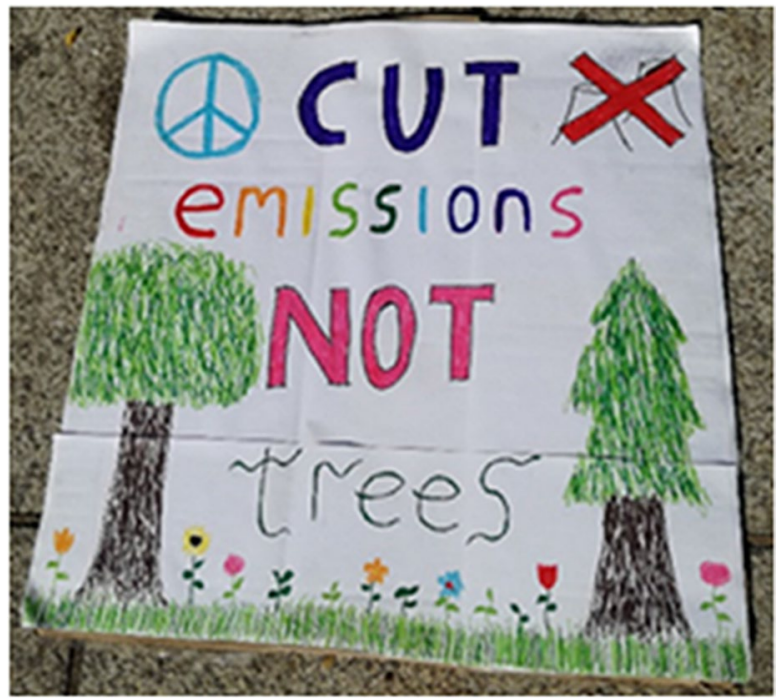

all kinds, young environmental activists tend to engage in processes of world-building rather than world-saving. As one participant in our study, a 16-year-old school student in Sheffield, Polly put it when talking about her involvement in the climate strikes and Extinction Rebellion:

My activism is not motivated by trying to save something, but it is by building something, in trying to make something new.

The "planetary emergency" depicted in the banner (see Photograph 1) in other words ought to be interpreted alongside the widely documented use by young people of slogans like "Change the system, not the climate!" (O'Brien et al. 2018) and "Systems change, not climate change!" (Bowman 2020). If "saving the world" figures in young environmental activist visions, it tends strongly to be a matter of juxtaposing living ecologies against death-dealing economies: 
Tom, 29, speaking in Trafalgar Square: "They are still investing trillions in fossil fuel endeavours that could be put into renewables when hundreds of species are dying... We need to have fundamental system change to survive and we need love of nature to survive. ... Let's try to save life on earth, or we won't be able to live on this planet".

Climate peace represents a useful framework for understanding the juxtaposition of life and destruction that rests at the heart of young environmentalism of this kind. In Tom's quote above, by way of illustration, this young environmental activist's critique of the "system" rings a similar note to Shiva's sense of a "war economy" against the Earth (2012: 5), and an economic system founded on maximum extraction. Tom, like many young environmental activists, also explores possible solutions and visions of a better future and climate peace. In the illustration above, Tom identifies a realignment of investments that "could be put into renewables". Divestment from fossil fuels figures here as a plausible component of a better future but should not be read as a simple fix, nor a target for policy change, without embedding it in Tom's wider call for "fundamental system change". Mickey, 17, in Manchester, described their action as "... making a stand against the systematic oppression that is happening". Climate peace, as young environmental activists like Tom and Mickey described it to us, is a positive peace rather than a negative peace. It is the process of building new processes and systems of energy generation and so forth that commit less climate violence. It is also the practice of dissent from and change to social and political systems of "oppression" that lie behind climate change, including police violence.

\section{Conclusion}

Young people are in a precarious situation as the world teeters on the precipice of a worsening climate crisis. In this article, we offer the concept of climate peace as a way to understand and explore young environmentalist activism from the positions of young people themselves. Climate peace, we argue, is a transformative approach in young environmental activism that upholds and acts for justice and interdependence. For this reason, we conceptualize climate peace as a positive form of peace. Young environmental activists do not wish to pacify climate change, nor to advocate for the mitigation of the effects of climate change as a form of slow violence-or at least not only for the mitigation of effects. In other words, young environmental activism does not begin with a policy demand or an allegiance to a political party, or other familiar markers of political activism. Rather, young environmental activism rests at the intersection of crises of global injustice. The activism of these young people begins with the search for conversations, commonground and communities, the process of imagining transformation, and the navigation of solidarities and positionalities among interdependent people and their environment. Young environmental activists are seeking to build climate peace from the grassroots up.

In this article, we reflected on the need to recognize and nurture the concept of positive peace. Young activists themselves speak of peace and non-violence. Yet, in public, policy and academic discourses concerning young people's environmental activism, peace is 
almost always conceptualized in its negative form, as the absence of violence. When people, including young demonstrators themselves, speak of peace, they almost always speak of negative peace: peaceful protest, non-violence at demonstrations and the commitment among protesters to relinquish tactics of interpersonal violence as political tools. However, we suggest, the process of defining peace as the mere absence of violence constrains the utility of peace as a unit of analysis when considering young people's environmental activism. This may restrict young people themselves in exploring concepts of peace as they pertain to social and political action.

For these reasons, we urge fellow scholars to embrace methods and theoretical concepts that are grounded in the knowledge and experience of young people themselves. Youth-centred methods and concepts are especially vital when assessing young people's dissent. In a period of youth-led non-violent direct action around the world about a variety of issues, we advocate a step change in the approach to young dissent, and young people's concepts of peace and non-violence, both among those who identify as activists and those who do not.

Acknowledgements We would like to thank Dena Arya for her role in this research project, including allowing us to cite young environmental activists interviewed by her and one of the authors, and their contributions to planning and developing the research method.

\section{Declarations}

Ethics Approval The fieldwork for this study was carried out with institutional approval from the Faculty of Arts and Humanities Research Ethics Committee, Manchester Metropolitan University, approval ID 11826 , on $19 / 08 / 2019$. The research was conducted in accordance with the principles embodied in the Declaration of Helsinki and in accordance with local statutory requirements. All participants gave written informed consent to participate in the study. Consent was given for publication by all participants.

Conflict of Interest The authors declare no competing interests.

Open Access This article is licensed under a Creative Commons Attribution 4.0 International License, which permits use, sharing, adaptation, distribution and reproduction in any medium or format, as long as you give appropriate credit to the original author(s) and the source, provide a link to the Creative Commons licence, and indicate if changes were made. The images or other third party material in this article are included in the article's Creative Commons licence, unless indicated otherwise in a credit line to the material. If material is not included in the article's Creative Commons licence and your intended use is not permitted by statutory regulation or exceeds the permitted use, you will need to obtain permission directly from the copyright holder. To view a copy of this licence, visit http://creativecommons.org/licen ses/by/4.0/.

\section{References}

Andretta M, della Porta D (2020) When millennials protest. In: Cuzzocrea V, Giovanna Bello B, Kazepov Y (eds) Italian Youth in International Context. Routledge, London, pp 41-57

Bessant J (2021) Making-up people: youth, truth and politics. Routledge, London

Bickmore K (2005) Foundations for peacebuilding and discursive peacekeeping: infusion and exclusion of conflict in Canadian public school curricula. J Peace Educ 2(2):161-181. https://doi.org/10.1080/ 17400200500173576 
Bickmore K (2011) Policies and programming for safer schools: are "anti-bullying" approaches impeding education for peacebuilding? Educ Policy 25(4):648-687. https://doi.org/10.1177/0895904810374849

Bowman B (2019) Imagining future worlds alongside young climate activists: a new framework for research. Fennia Int J Geogr 197(2):295-305

Bowman B (2020) 'They don't quite understand the importance of what we're doing today': the young people's climate strikes as subaltern activism. Sust Earth 3(16). https://doi.org/10.1186/s42055-020-00038-X

Brantmeier EJ (2007) Everyday understandings of peace and non-peace: peacekeeping and peacebuilding at a US Midwestern high school. J Peace Educ 4(2):127-148. https://doi.org/10.1080/17400200701523520

Chevalier T, Loncle P (2021) Une jeunesse sacrifiée? Presses universitaire de France, Paris

Collin P, Matthews I (2021) School strike for climate: Australian students renegotiating citizenship. In: Bessant J, Mejia Mesinas A, Pickard S (eds) When students protest: secondary and high schools, vol 1. Rowman and Littlefield, Washington, pp 125-144

Curnow J, Helferty A (2018) Contradictions of solidarity. Whiteness, Settler Coloniality, and the Mainstream Environmental Movement. Environ Soc 9(1):141-163. https://doi.org/10.3167/ares.2018.090110

Francis D (2010) From Pacification to Peacebuilding: A Call to Global Transformation. Pluto Press, London

Francis D (2011) New thoughts on power: closing the gaps between theory and action. In: Austin B, Fischer M, Gießmann HJ (eds) Berghof handbook for conflict transformation. Berghof, Berlin, pp 506-525

Francis D (2011b) From pacification to peacebuilding: a call to global transformation. Pluto Press, London

Fisher SR (2016) Life trajectories of youth committing to climate activism. Environ Educ Res 22(2):229247. https://doi.org/10.1080/13504622.2015.1007337

Foran J (2019) Manifesto for a sociology of the climate crisis and of climate justice. In: Bhavanani KK, Foran J, Kurian P, Munshi D (eds) Climate Futures. Reimagining global climate justice. Zed, London

Galtung J (1969) Violence, peace, and peace research. J Peace Res 6(3):167-191. https://doi.org/10.1177/ 002234336900600301

Gilmore J, Jackson W, Monk H (2019) 'That is not facilitating peaceful protest. That is dismantling the protest': anti-fracking protesters' experiences of dialogue policing and mass arrest. Polic Secur 29(1):36-51. https://doi.org/10.1080/10439463.2017.1319365

Grasso M (2017) Young people's political participation in Europe in times of crisis. In: Pickard S, Bessant J (eds) Young people re-generating politics in times of crises. Palgrave Macmillan, London, pp 179-196

Hayward B (2021) Children, citizenship and environment. SchoolStrike edition. Earthscan, Routledge, London

Henn M, Weinstein M, Wring D (2002) A generation apart? Youth and political participation in Britain. Br J Polit Int Relat 4(2):167-192. https://doi.org/10.1111/1467-856X.t01-1-00001

Isin E (2005) Engaging, being, political. Polit Geogr 24(3):373-387. https://doi.org/10.1016/j.polgeo.2004.07.002

Järvikoski T (1995) Young people as actors in the environmental movement. Young 3(3):80-93. https:// doi.org/10.1177/110330889500300306

King ML Jr (2016) The radical king. Beacon Press, Boston

Kishinani P, Smith M (2020) Student guide to the climate crisis. Manchester: Climate Emergency Manchester. Available at https://climateemergencymanchester.net/student-climate-handbook. Accessed 2 Mar 2021

Kurtenbach S (2017) Neglected or criminalized: the need for youth inclusion in peacebuilding. Oxford Research Group, London

Muncie E (2019) 'Peaceful protesters' and 'dangerous criminals': the framing and reframing of anti-fracking activists in the UK. Soc Mov Stud 19(4):464-481. https://doi.org/10.1080/14742837.2019.1708309

McEvoy-Levy S (2011) Children, youth, and peacebuilding. In: Matyók T (ed) Critical issues in peace and conflict studies: theory, practice, and pedagogy. Lexington Books, London, pp 159-176

Nissen S, Wong JHK, Carlton S (2021) Children and young people's climate crisis activism - a perspective on long-term effects. Children's Geog 19(3):317-323. https://doi.org/10.1080/14733285.2020.1812535

Nixon R (2011) Slow violence and the environmentalism of the poor. Harvard University Press, Cambridge

O'Brien K, Selboe E, Hayward B (2018) Exploring youth activism on climate change: dutiful, disruptive, and dangerous dissent. Ecol Soc 23(3):42. https://doi.org/10.5751/ES-10287-230342

Panu P (2020) Anxiety and the Ecological Crisis: An Analysis of Eco-Anxiety and Climate Anxiety. Sustainability 12(19):7836. https://doi.org/10.3390/su12197836

Pickard S (2014) Keep Them Kettled! Student Protests, Policing and Anti-social Behaviour. In: Pickard S (ed) Anti-social Behaviour in Britain. Palgrave Macmillan, London, pp 77-91

Pickard S (2019) Politics, protest and young people: political participation and dissent in 21st century Britain. Palgrave Macmillan, London

Pickard S (2021) You are stealing our future in front of our very eyes. The representation of climate change, emotions and the mobilisation of young environmental activists in Britain. E-rea, 18(2). https://doi.org/10.4000/erea.11774 
Pickard S, Bowman B, Arya D (2020) "We are radical in our kindness": the political socialisation, motivations, demands and protest actions of young environmental activists in Britain. Youth Glob 2(2):251-280

Pihkala P (2017) Environmental education after sustainability: hope in the midst of tragedy. Glob Discourse 7(1):109-127. https://doi.org/10.1080/23269995.2017.1300412

Pontes AI, Henn M, Mark D, Griffiths MD (2019) Youth political (dis)engagement and the need for citizenship education: Encouraging young people's civic and political participation through the curriculum. Educ Citizsh Soc Justice 14(1):3-21. https://doi.org/10.1177/1746197917734542

Power N (2012) Dangerous subjects: UK students and the criminalization of protest. South Atlantic Q 111(2):412-420. https://doi.org/10.1215/00382876-1548311

Pulido L (1997) Community, place and identity. In: Jones JP, Nast HJ, Roberts SM (eds) Thresholds in feminist geography: difference, methodology, representation. Rowman \& Littlefield, Washington, pp 11-28

Pulido L (1996) Environmentalism and economic justice: two Chicano struggles in the southwest. University of Arizona Press, Tucson

Roque S (2017) Between new terrains and old dichotomies: peacebuilding and the gangs' truce in El Salvador. Contexto Int 39(3). https://doi.org/10.1590/s0102-8529.2017390300003

Sloam J (2020) Young Londoners, sustainability and everyday politics: the framing of environmental issues in a global city. Sustain Earth 3(14):1-7. https://doi.org/10.1186/s42055-020-00036-z

Schinko T (2020) Overcoming political climate-change apathy in the era of \#FridaysForFuture. One Earth 2(1):20-23. https://doi.org/10.1016/j.oneear.2019.12.012

Shiva V (2012) Making peace with the earth: beyond resource, land and food wars. Women Unlimited

Skelton T (2010) Taking young people as political actors seriously: opening the borders of political geography. Area 42(2):145-151. https://doi.org/10.1111/j.1475-4762.2009.00891.x

Shiva V (2019) Foreword. In: Farrell C, Green A, Knights S, Skeaping W (eds) This is not a drill. An extinction rebellion handbook. Penguin, London, pp 5-8

Taft J, Gordon H (2013) Youth activists, youth councils, and constrained democracy. Educ Citizenship Soc Justice 8(1):87-100. https://doi.org/10.1177/1746197913475765

Thew H, Middlemiss L, Paavola, J (2020) "Youth is not a political position": exploring justice claimsmaking in the UN Climate Change Negotiations. Glob Environ Chang 20. https://doi.org/10.1016/j. gloenvcha.2020.102036

Tilly C (2003) The politics of collective violence. Cambridge University Press, Cambridge

Trajber R, Walker C, Marchezini V, Kraftl P, Olivato D, Hadfield-Hill S, Zara C, Fernandes Monteiro S (2019) Promoting climate change transformation with young people in Brazil: participatory action research through a looping approach. Action Res 17(1):87-107. https://doi.org/10.1177/1476750319829202

Thunberg G (2019) Speech at The United Nations Climate Action Summit. New York, 23 September 2019. https://www.nbcnews.com/news/world/read-greta-thunberg-s-full-speech-united-nations-clima te-action-n1057861. Accessed 6 Dec 2021

Watts R (2021) Theorizing student protest. In: Bessant J, Mejia Mesinas A, Pickard S (eds) When students protest secondary and high school students, vol 1. Rowman and Littlefield, Washington, pp 13-24

Wood BE (2020) Youth-led climate strikes: fresh opportunities and enduring challenges for youth research - commentary to Bowman. Fennia 198(1):217-222. https://doi.org/10.11143/fennia.91089

Wood BE, Taylor R, Atkins R (2018) Student voice, citizenship and regulated Spaces. In: Bourke R, Loveridge J (eds) Radical Collegiality Through Student Voice: Educational Experience, Policy and Practice. Springer Singapore, Singapore, pp 179-196

Young-Bruel E (2012) Childism: confronting prejudice against children. Yale University Press, New Haven

\section{Authors and Affiliations}

\section{Benjamin Bowman ${ }^{1}$ D $\cdot$ Sarah Pickard ${ }^{2}$ (D)}

Sarah Pickard

sarah.pickard@sorbonne-nouvelle.fr

1 Manchester Metropolitan University, Geoffrey Manton 14, Rosamund St. West, Manchester M15 6LL, UK

2 Université Sorbonne Nouvelle, Paris 3, France 